\title{
Co-learning cycles to support the design of innovative farm systems in southern Mali
}

\author{
Gatien N. Falconnier ${ }^{\mathrm{a}, *}$, Katrien Descheemaeker ${ }^{\mathrm{b}}$, Thomas A. Van Mourik ${ }^{\mathrm{c}}$, Myriam Adam ${ }^{\mathrm{d}, \mathrm{e}}$, \\ Bougouna Sogoba ${ }^{\mathrm{f}}$, Ken E. Giller ${ }^{\mathrm{b}}$ \\ a AGIR, Université de Toulouse, INPT, INP-PURPAN, INRA, 31320 Castanet Tolosan, France \\ b Plant Production Systems, Wageningen University, P O Box 430, 6700 AK Wageningen, The Netherlands \\ c Helen Keller International, Africa Regional Office, P O Box 29.898, Yoff, Toundoup Rya Lot 122, Route de l'aeroport, Dakar, Senegal \\ d CIRAD, UMR AGAP/PAM, Av. Agropolis, Montpellier, France \\ e International Crops Research Institute for the Semi-Arid Tropics (ICRISAT), BP320, Bamako, Mali \\ ${ }^{\mathrm{f}}$ Association Malienne d'Eveil au Developpement Durable (AMEDD), Darsalam II, Route de Ségou, BP 212 Koutiala, Mali
}

\section{A R T I C L E I N F O}

\section{Keywords:}

Food self-sufficiency

Income

Ex ante trade-off analysis

Participatory research

\begin{abstract}
A B S T R A C T
Farm systems were re-designed together with farmers during three years (2013-2015) in Southern Mali with the aim to improve income without compromising food self-sufficiency. A cyclical learning model with three steps was used: Step 1 was the co-design of a set of crop/livestock technical options, Step 2 the on-farm testing and appraisal of these options and Step 3 a participatory ex-ante analysis of re-designed farm systems incorporating the tested options. Two iterations of the cycle were performed, in order to incorporate farmers' point of view and researchers' learning. We worked together with 132 farmers representing four farm types: High Resource Endowed with Large Herd (HRE-LH); High Resource Endowed (HRE); Medium Resource Endowed (MRE) and Low Resource Endowed (LRE) farms. In the first cycle of 2012-2014 farmers re-designed their farms and the reconfigurations were assessed ex ante using the average yields and gross margins obtained in the 2013 on-farm trials. HRE-LH farmers experienced a disappointing decrease in food self-sufficiency and MRE farmers were disappointed by the marginal improvement in gross margin. In a second cycle in 2014-2015, farmer insights gathered during field days and statistical analysis of trial results allowed a better understanding of the variability of option performance and the link with farm context: niches were identified within the farms (soil type/previous crop combinations) where options performed better. The farm systems were re-designed using this nichespecific information on yield and gross margin, which solved the concerns voiced by farmers during the first cycle. Without compromising food self-sufficiency, maize/cowpea intercropping in the right niche combined with stall feeding increased HRE-LH and HRE farm gross margin by 20-26\% respectively (i.e. 690 and 545 US\$ year ${ }^{-1}$ ) with respect to the current farm system. Replacement of sorghum by soyabean (or cowpea) increased MRE and LRE farm gross margin by 29 and $9 \%$ respectively (i.e. 545 and 32 US $\$$ year $^{-1}$ ). Farmers highlighted the saliency of the niches and the re-designed farm system, and indicated that the extra income could be reinvested in the farm. Our study demonstrates the feasibility and the usefulness of a cyclical and adaptive combination of participatory approaches, on-farm trials and ex-ante analysis to foster learning by farmers and researchers, allowing an agile reorientation of project actions and the generation of innovative farm systems that improve farm income without compromising food self-sufficiency. The re-designed farm systems based on simple, reproducible guidelines such as farm type, previous crop and soil type can be scaled-out by extension workers and guide priority setting in (agricultural) policies and institutional development.
\end{abstract}

\section{Introduction}

Farming system design can help to generate innovative farm systems to overcome the constraints faced by farmers, increase farm productivity and profitability, and improve households' livelihoods.
Farming system design employs qualitative and quantitative approaches to support the analysis of current farm systems and the design and evaluation of alternatives (Le Gal et al., 2011; Martin et al., 2012). Farm systems are highly heterogeneous in terms of resource endowment, soil types, cropping and livestock systems, and livelihood

\footnotetext{
* Corresponding author.

E-mail addresses: falconniergatien@yahoo.fr, gatien.falconnier@inra.fr (G.N. Falconnier).
} 
strategies (Giller et al., 2011). This implies the need to tailor innovations to the context of the farm (Descheemaeker et al., 2016b). Tailoring innovations can be facilitated firstly by farm typologies, which are a useful tool to consider heterogeneity of resource endowment and/ or production objectives (Chopin et al., 2014; Senthilkumar et al., 2012; Tittonell et al., 2010). Secondly, strong farmers' participation in the design process may enhance the relevance of the innovations for specific farmer contexts (Schaap et al., 2013). While participatory research mainly generates qualitative insights (Dorward et al., 2003; Van Asten et al., 2009), Participatory Learning and Action Research (PLAR) was proposed to combine qualitative and quantitative insights (Defoer, 2002). In PLAR, qualitative participatory research provides information that strengthens quantitative assessments, e.g. resource flow maps drawn by farmers to derive and calculate nutrient balances. Similarly, Martin et al. (2012) employed a game board to redesign livestock systems in France. In this approach, inputs from farmers playing the game were used to calculate indicators (e.g. satisfaction of animal needs) with the help of a computerized support system. Conversely, Paassen et al. (2011) showed that quantitative outputs of multiple goal linear programming models, if presented using concepts and symbols familiar to farmers, enhanced communication between farmers, farm advisors and researchers leading to relevant farm-specific solutions. In other studies, outputs from simple models (static simulation of annual farm stocks and flows), representing farmers' reality and concerns were an appropriate discussion support to jointly generate alternative farm systems (Sempore et al., 2015; Andrieu et al., 2015).

The approach of combining ex-ante trade-off analysis and on-farm trials in iterative learning cycles with farmers has been conceptualised in the Describe Explain Explore Design (DEED) cycle (Descheemaeker et al., 2016b; Giller et al., 2011). Where DEED was applied previously, it produced useful insights to re-design farm systems: e.g. strategies to restore soil fertility led to improved crop and cattle productivity at village scale (Rufino et al., 2011), land allocation to fodder and use of an improved cattle breed resulted in improved farm recycling efficiency (Tittonell et al., 2009). However, most existing studies applied only one DEED cycle. Having a second cycle allows to incorporate the learning from the first cycle, but there is little insight into how methods and solutions can be adapted dynamically using scientific results and farmers' appraisals (a useful exception is Dogliotti et al. (2014)). Furthermore, modelling outputs have seldom been coupled to real on-farm testing, although farmers were usually willing to test the different technical alternatives (urea treatment of straw, compost pits) in their farms (Andrieu et al., 2012). Finally, though the empowerment of stakeholders during the participatory process is widely acknowledged (de Jager et al., 2009; Defoer, 2002; Hellin et al., 2008; Sterk et al., 2007), there is little empirical evidence that a participatory approach can increase the scaling-out potential of the research outputs (Sumberg et al., 2003).

Land shortage, climate variability and climate change (Descheemaeker et al., 2016a), unreliable institutional support (e.g. fertiliser subsidy) for crop production (Ebanyat et al., 2010), decreasing fodder availability for livestock, weak access to output markets for livestock products, and poor price setting power for cereals and livestock (Kaminski et al., 2013) are common challenges for smallholders across sub-Saharan Africa. Also the farmers in southern Mali face these constraints (Autfray et al., 2012; Coulibaly et al., 2015; Traore et al., 2013). Technical alternatives at field/cow scale (e.g. diversification with legumes, stall feeding of cows) can help farmers to cope with the challenging characteristics of their environment. These alternatives can be tested in on-farm trials. Strategic/tactical decisions (Le Gal et al., 2010) like changing field area per crop, producing a new type of fodder and/ or changing the feeding strategy of cows need to be addressed at farm scale. Given the risk involved, this is often done with ex-ante analysis (Whitbread et al., 2010). Such major changes made at farm level can be referred to as "innovative farm systems" (Le Gal et al., 2011). In southern Mali, achieving food self-sufficiency and improving farm income are farmers' main objectives (Bosma et al., 1999). An assessment of the performance of the innovations is thus needed, using relevant indicators like yield, gross margin and Cost:Benefit for technical alternatives and food self-sufficiency and income for innovative farm systems.

The objectives of this study were to (i) design innovative farm systems that improve farm income without compromising food selfsufficiency in the cotton area of southern Mali, (ii) implement the DEED cycle twice with emphasis on on-farm testing of technical alternatives, ex-ante impact assessment through modelling, and incorporation of farmers' and researchers' learning, (iii) illustrate the feasibility and usefulness of such an approach through its ability to generate salient farm systems for farmers and practical scaling-out guidelines for extension workers. In what follows, we start by describing the different steps and their adaptation during the learning cycles. The second section presents the assessment of the agro-economic performance of the tested innovations and an analysis of farmers' and researchers' learning during the cycles. The last section discusses (i) adaptation of the research methods as a key feature of this farming system design approach, (ii) the strength of the guidelines generated, (iii) the opportunities for scaling out and (iv) the broader changes needed to trigger large-scale adoption of the innovative designs.

\section{Methods}

\subsection{Study area and farm characteristics}

The study area is located in Koutiala district in the cotton zone of southern Mali where population densities reach 70 people $\mathrm{km}^{-2}$ (Soumaré et al., 2008). The uni-modal rainy season starts in May and ends in October, with total annual rainfall ranging from 500 to $1200 \mathrm{~mm}$. Farmers grow maize, sorghum and millet for food consumption and cotton and groundnut to generate income. Livestock provide draught power, milk, meat, manure, and a buffer against risk (Kanté, 2001). Farming is the major livelihood strategy, with achieving food self-sufficiency the farmers' main objective (Bosma et al., 1999) and cash-oriented non-farm activities providing a small (12\%) but important share of the income per capita (Losch et al., 2012). A typology based on farm resource endowment (household size, number of workers, total cropped land, number of draft tools and herd size expressed in TLU, i.e. a Tropical Livestock Unit of $250 \mathrm{~kg}$ ) distinguished four farm types in the Koutiala district: (1) High Resource Endowed Farms with Large Herds (HRE-LH) (on average 28 workers cultivating 17 ha with 4 draught tools and a herd of 46 TLU), (2) High Resource Endowed (HRE) farms (on average 18 workers cultivating 12 ha, with 4 draught tools and a herd of 8 TLU), (3) Medium Resource Endowed (MRE) farms (on average 7 workers cultivating 8 ha with 5 draught tools and a herd of 6 TLU) and (4) Low Resource Endowed (LRE) farms (on average 5 workers cultivating 3 ha with 1 draught tool and a herd of 2 TLU) (Falconnier et al., 2015).

Farmers participating in this research originated from nine neighbouring villages of the Koutiala district: M'Peresso, Nitabougouro, Nampossela, Finkoloni, Try, Koumbri, Karangasso, N'Goukan and Kani. In total, 132 farmers participated in this study (from 12 to 16 per village). The share of HRE-LH, HRE, MRE and LRE farms among the participating farmers was close to the average share in the villages of the Koutiala region (Falconnier et al., 2015), i.e. 22, 44, 24 and $11 \%$ respectively. Scientific activities were carried out by researchers from three research institutes, the International Crops Research Institutes for the Semi-Arid Tropics (ICRISAT), Institut d'Economie Rurale (IER) and Wageningen University, while interactions between farmers and researchers were facilitated by people belonging to a Malian NGO, the Association Malienne pour l'Eveil au Développement Durable (AMEDD). During the group discussions, the facilitators helped to create an inclusive environment, encouraged participants to share their ideas and kept discussions on track. 
During the design process farmers and researchers interacted most intensively in M'Peresso, Nitabougouro and Nampossela, further referred to as the three "core villages". In 2013, farm characteristics, i.e. size of the household, cropping patterns per soil type, livestock herd size and composition were recorded for 35 participating farms in the three core villages.

\subsection{Series of steps and cycles in the design process}

The design process consisted of three steps: Step 1. Design of a set of technical options (at field/cow scale) based on farmers' constraints and opportunities; Step 2. On-farm testing and appraisal of options; and Step 3. Ex ante trade-off analysis of re-designed farm systems. Step 2 and Step 3 together formed one cycle, which was carried out twice. Each step provided inputs and insights to the other (Fig. 1). In 2013-2014, Step 1 was followed by a first cycle (T1) of Step 2 and Step 3. In 2014-2015, in order to incorporate insights from T1, a second cycle (T2) of Step 2 and Step 3 was carried out (Fig. 1).

Step 1 corresponds to the Describe phase of the DEED cycle, Step 2 encompasses Describe and Explain components, while Step 3 encompasses Explore and Design components of the DEED cycle. In Fig. 1 we refer to tables and figures that illustrate and explain each step and sub-step. Tables and figures that are not essential to the understanding of the paper are not mentioned in the text of the paper and are put in supplementary material as background and resource for readers who are interested to repeat this exercise. Below we describe the steps and cycles in detail.

\subsection{Step 1: design of a set of options based on farmers' constraints and opportunities}

One participatory rural appraisal (PRA) was held in each of the three core villages, each involving 40-50 farmers invited over three days (no selection criteria). Farmers were asked to collectively list (i) the constraints to crop growing for food self-sufficiency and income generation, and to livestock rearing and (ii) the opportunities to solve these constraints. Based on the opportunities identified during the PRA, a range of options for farm performance improvement was discussed. The budget and the particular skills and expertise of the partners of this project logically limited the scope of what could be tested. Hence, in planning workshops, researchers and farmers jointly decided which options could be tested. Among the opportunities mentioned by farmers, technical opportunities rather than organisational issues (e.g. access to credit) were selected, and opportunities for which farmers had received little training so far from development actors, were prioritized. Farmers indicated the improved varieties they wanted to test (e.g. maize and sorghum hybrids) and after discussion with researchers the different management practices to consider (fertilisation or not, intercropping patterns) were defined.

\subsection{Step 2: on-farm testing and appraisal of farm improvement options}

\subsubsection{General description of step 2}

Step 2 consisted of: i) the testing of options by farmers, ii) a farmer field day during the crop growing season, iii) the scientific analysis of trial results, and iv) a feedback session including farmers' appraisal of trial results (Fig. 1). Farmers of the nine participating villages tested crop options in 2013 and 2014. Farmers volunteered to get involved in the trials, with a limit of maximum 16 farmers per village and at least one farmer from each farm type. A total of 372 on-farm trials was conducted in farmers' fields across the nine villages during the whole process. Each farmer could choose to implement one or more trials each year. A crop trial was a combination of four treatments, i.e. the current cropping practice as a control, a first option, a second option and the
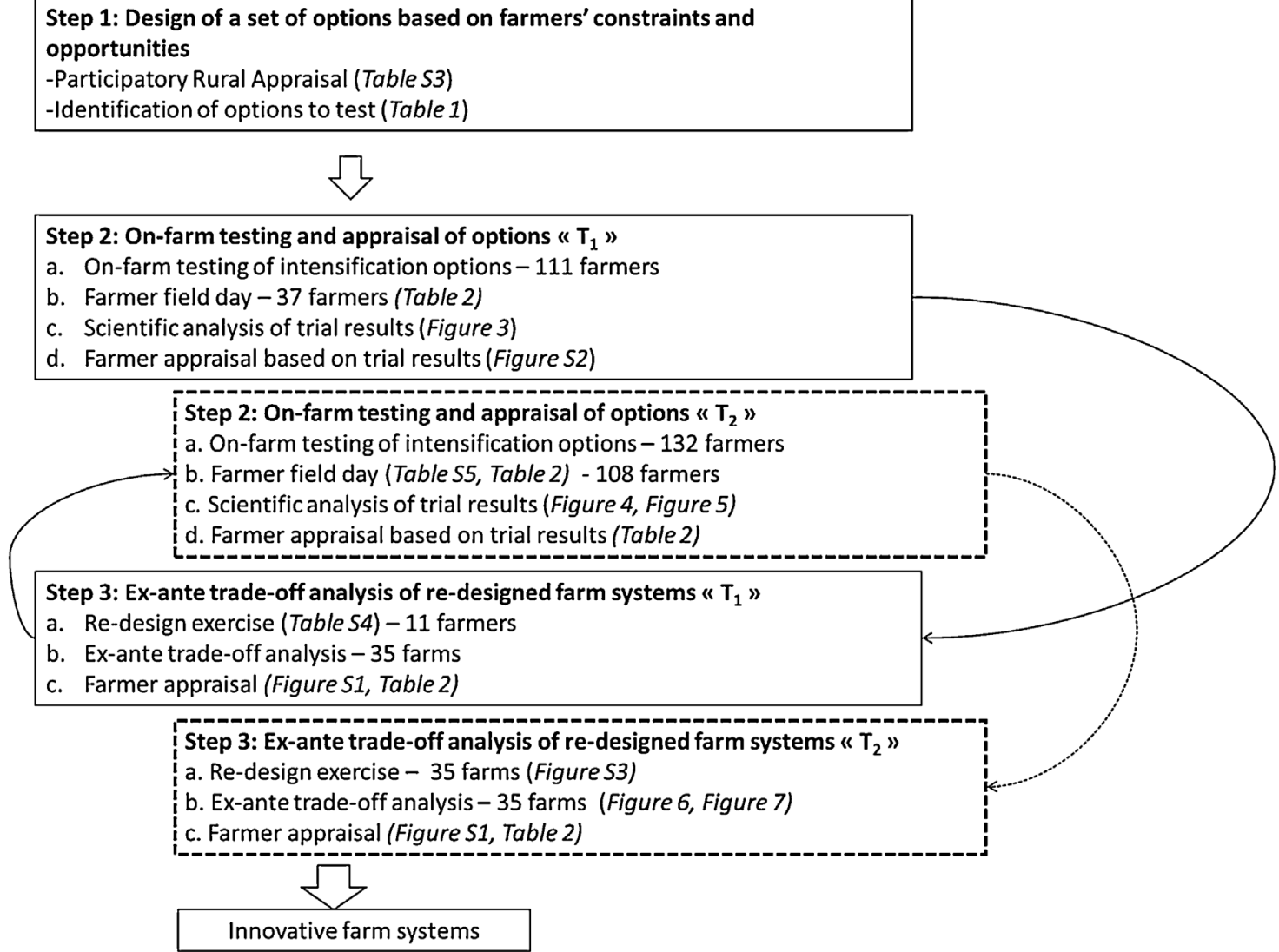

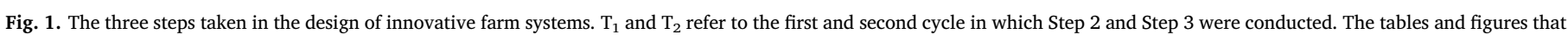
illustrate the different steps are mentioned in parenthesis. 
combination of the two options. The trials contained all the different crop options designed by researchers and farmers and there were seven different crop trials: maize, sorghum, groundnut, cowpea, soyabean, maize/cowpea intercropping and sorghum/cowpea intercropping (Table 1). A more detailed description of the crop trials' setup and treatments can be found in Falconnier et al. (2016). Farmers planted and managed the trials with the help and monitoring of a field agent. Inputs (seeds of local and improved varieties, fertilizer, inoculum) and financial support to participate to workshops were provided by the project. The livestock trial was executed during the 2014 dry hot season with one to five cows per farm receiving different feeding strategies based on De Ridder et al. (2015), namely (i) the farmer practice (grazing of common grassland and residue grazing of cropland), (ii) a supplemented diet (as current farmer practice with extra $1 \mathrm{~kg}$ cowpea hay day ${ }^{-1}$ and $1.5 \mathrm{~kg}$ cotton seed cake day ${ }^{-1}$, and iii) animals kept in the stall with $2.5 \mathrm{~kg}$ cowpea hay day ${ }^{-1}, 2 \mathrm{~kg}$ cotton seed cake day ${ }^{-1}$ and $4 \mathrm{~kg}$ cereal residues day ${ }^{-1}$.

\subsubsection{First cycle of step 2 (2013)}

In total, 111 farmers of the nine participating villages tested the crop options during the 2013 growing season. During a farmer field day in October 2013, 37 participating farmers from the three core villages visited all trial types in their colleagues' fields to familiarize with the options not tested on their own farm. Discussions focused on the description of the treatments and the observed effects. After harvest, gross margin was calculated (assuming all products were sold) as the difference between (i) grain production (and stover production for cowpea) multiplied by the market price and (ii) the variable costs (e.g. seed, fertiliser, inoculant). Output prices and input costs were obtained from a market analysis carried out in 2013. Labour and manure produced on farm were not included as costs. In April 2014, average yield and gross margins of options were presented to the participating farmers during workshops in each village. Posters with drawings symbolized the different options, their yield and gross margin in farmers' units (e.g. harvest in bags of grains). In the three core villages, 30 farmers evaluated the options by distributing 15 stones among the options they appreciated most. Ten volunteer farmers from the core village tested the livestock options during the dry season of 2014 with a total of 24 lactating cows. In May 2014, all participating farmers from the core villages visited the livestock trials. The livestock trials were used as demonstrations for farmers. For the ex-ante trade-off analysis, we used the data from previously published livestock experiments with similar treatments (see section 2.5.1).

Table 1

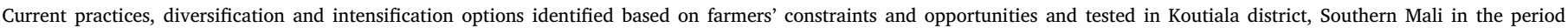
2013-2014. Local names and cultivar names of crop varieties are indicated in quote and under brackets respectively.

\begin{tabular}{|c|c|c|}
\hline & Details & Extra cost* (US\$ ha ${ }^{-1}$ ) \\
\hline \multicolumn{3}{|c|}{ Current cropping practices } \\
\hline \multirow[t]{2}{*}{ Maize } & Local variety "Dembanyuma" + mineral fertiliser & - \\
\hline & Local variety "Dembanyuma" + mineral fertiliser + manure & - \\
\hline Sorghum & Local variety"Segetana" & - \\
\hline Groundnut $^{\mathrm{a}}$ & Local variety "Kampiani" & - \\
\hline \multicolumn{3}{|c|}{ Current livestock feeding practices during the dry hot season } \\
\hline Lactating cows & Open grazing & - \\
\hline \multicolumn{3}{|c|}{ A) Intensification of current crops } \\
\hline \multirow[t]{6}{*}{ Maize } & Hybrid "Bondofa" (EV8444 SR × SR22a) + mineral fertiliser & 95 \\
\hline & Hybrid "Bondofa" (EV8444 SR × SR22a) + mineral fertiliser + manure & 95 \\
\hline & Intercropped with cowpea grain variety "Wulibali" (IT $90 \mathrm{~K} 372-1-2$ ), additive ${ }^{\mathrm{a}}$ pattern & 14 \\
\hline & Intercropped with cowpea grain variety "Wulibali" (IT $90 \mathrm{~K} 372-1-2$ ), substitutive ${ }^{\mathrm{b}}$ pattern & 8 \\
\hline & Intercropped with cowpea fodder variety "Dounanfana" (PBL 112), additive ${ }^{\mathrm{a}}$ pattern & 16 \\
\hline & Intercropped with cowpea fodder variety "Dounanfana" (PBL 112), substitutive ${ }^{\mathrm{b}}$ pattern & 9 \\
\hline \multirow[t]{7}{*}{ Sorghum } & Local variety "Segetana" + mineral fertiliser + manure & 60 \\
\hline & Hybrid "Pablo" (FambeA $\times$ Lata) & 14 \\
\hline & Hybrid "Pablo" (FambeA $\times$ Lata) + mineral fertiliser + manure & 74 \\
\hline & Intercropped with cowpea grain variety "Wulibali" (IT $90 \mathrm{~K} 372-1-2$ ), additive ${ }^{\text {a }}$ pattern & 14 \\
\hline & Intercropped with cowpea grain variety "Wulibali" (IT $90 \mathrm{~K} 372-1-2$ ), substitutive ${ }^{\mathrm{b}}$ pattern & 9 \\
\hline & Intercropped with cowpea fodder variety "Dounanfana" (PBL 112), additive ${ }^{\mathrm{a}}$ pattern & 16 \\
\hline & Intercropped with cowpea fodder variety "Dounanfana" (PBL 112), substitutive ${ }^{\mathrm{b}}$ pattern & 11 \\
\hline Groundnut $^{\mathrm{c}}$ & Improved variety (ICGV 86124b) & 34 \\
\hline \multicolumn{3}{|c|}{ B) Diversification crops without extra inputs } \\
\hline \multirow[t]{2}{*}{ Cowpea } & Improved grain variety “Wulibali” (IT $90 \mathrm{~K}$ 372-1-2) & - \\
\hline & Improved fodder variety "Dounanfana” (PBL 112) & - \\
\hline Soyabean & Improved variety "Houla1" & - \\
\hline \multicolumn{3}{|c|}{ C) Intensification of diversification crops } \\
\hline \multirow[t]{2}{*}{ Cowpea } & Improved grain variety "Wulibali" (IT $90 \mathrm{~K}$ 372-1-2) + P fertiliser & 80 \\
\hline & Improved fodder variety "Dounanfana" (PBL 112) + P fertiliser & 80 \\
\hline \multirow[t]{3}{*}{ Soyabean } & Improved variety "Houla1" + (P fertiliser + manure $)$ & 80 \\
\hline & Improved variety "Houla1" + Inoculum & 25 \\
\hline & Improved variety "Houla1" + (P fertiliser + manure $)+$ Inoculum & 105 \\
\hline \multicolumn{3}{|c|}{ D) Improved livestock feeding during dry hot season (March-June) } \\
\hline \multirow[t]{2}{*}{ Lactating cows } & Supplemented & 67 \\
\hline & Stall fed & 67 \\
\hline
\end{tabular}

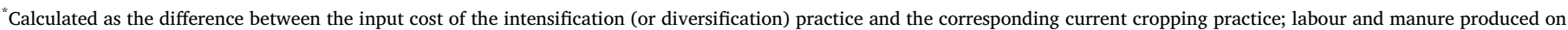
farm were not included as costs.

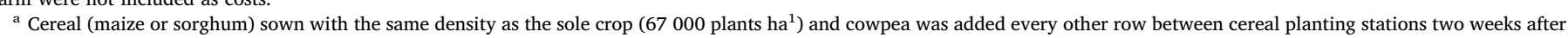
the cereal (giving a cowpea density of 33500 plants ha $^{1}$ ).

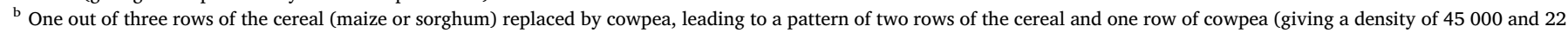
000 plants ha ${ }^{1}$ for cereal and cowpea respectively).

c Tested only in 2014 . 


\subsubsection{Second cycle of step 2 (2014)}

All participating farmers from the previous cycle and 21 additional farmers (132 farmers in total) tested the crop options in the 2014 growing season. The field day in September 2014 focused on understanding causes of yield variability. One visit to contrasting trials of the same type (a trial with 'poor' crop performance and a trial with 'good' crop performance) was organised in each of six different villages (Nampossela, Nitabougouro, M'Peresso, Try, N'Goukan and Karangasso) with a total of 108 participating farmers. In each trial, the group of farmers collectively scored the control and the different treatments based on a visual estimate of the yield $(1=$ poor, $2=$ medium, 3 = good, 4 = excellent) and gave reasons for this score. During discussions in the field, we recorded the factors mentioned by farmers to explain the observed differences in control yield and treatment effect among contrasting trials. These factors are further referred as "farmer-identified covariates". In order to explain yield variability, a statistical analysis was carried out on 2013 and 2014 data, using linear mixed models with treatment, farmer-identified covariates and season as fixed factors and the trial as a blocking random factor. Treatments included fertilisation, intercropping pattern, variety and inoculation and farmer-identified covariates included soil type and previous crop in the rotation (a detailed description of the analysis is given in Falconnier et al. (2016)). For further analysis in Step 3, yields were averaged per level of treatment/covariate (e.g. mineral fertilizer $=$ no, soil type $=$ gravelly soil) in case of a significant effect and otherwise averaged across the levels. Covariates were used to define niches (i.e. particular biophysical conditions constituted by the combinations of explanatory factors like soil type and previous crop) where options yielded best results. Additionally, treatments with extra input compared with farmer practice (e.g. inoculant, P fertiliser) were assessed based on Benefit:Cost ratio and risk. The Benefit:Cost ratio was computed as the difference in income between the treatment and the control divided by the extra cost incurred (Table 1). A Benefit:Cost ratio of at least two was considered as a practical threshold for adoption (Bielders and Gérard, 2015). Risk was assessed as the likelihood of generating a profit, i.e. a Benefit:Cost ratio higher than one, considering the variability across trial locations (Bielders and Gérard, 2015; Ronner et al., 2016). Following Bielders and Gérard (2015), having more than 50\% of the plots with a Benefit:Cost ratio lower than one was considered risky.

\subsection{Step 3: Ex ante trade-off analysis of re-designed farm systems}

\subsubsection{General approach}

Step 3 consisted of: i) a farm re-design exercise, ii) an ex ante tradeoff analysis of the re-designed farm systems focusing on the objectives of food self-sufficiency and income and iii) appraisal of the re-designed farm systems by farmers (Fig. 1).

Input data for the ex-ante trade-off analysis included (i) farm characteristics of 35 participating farms of the three core villages, i.e. the size of the household, cropping patterns per soil type, and livestock herd size and composition, (ii) the crop/livestock average productivity and gross margins of current practices and tested options, obtained in the on-farm trials (Table S1). For stall feeding of lactating cows, milk production obtained during the dry hot season was extrapolated to the whole year using results from year-round simulations of stall fed lactating cows of de Ridder et al. (2015). In order to integrate crop/animal level findings into a farm level analysis of gross margin and food selfsufficiency, a conceptual farm model with a household, cropland and cattle herd component was developed and used for the ex-ante analysis (Fig. 2). Crop rotation was included in the model, as it had to be able to deal with differential crop responses depending on previous crop and soil type. Cowpea fodder production was computed to determine the percentage of cows that could be fed in the stall.

The trade-off analysis was performed for individual farms and different degrees of crop replacement using simple calculations. Two indicators were computed for $0,20,40,60,80$ and $100 \%$ replacement and summarized per farm type: household food self-sufficiency (i.e. the ratio of on-farm cereal production over household cereals needs) and farm gross margin (i.e. the sum of the gross margins from cash crops, milk sales and cereal production above household needs). Farm gross margin was chosen as the indicator of income. The equations and intermediary indicators are detailed in Table S2. In order to take into account variation among the farm population (within a given farm type) for which the ex-ante analysis was run, we considered that food self-sufficiency was not compromised as long as the average food selfsufficiency (of all the farms) minus the standard error remained above the self-sufficiency threshold of one. The maximum replacement percentage of a crop by another was determined as the maximum percentage for which food self-sufficiency was not compromised. For each farm type, the average farm gross margin increase was recorded for this maximum rate of replacement.

We used the model and the ex-ante analysis as a tool to generate information that could help in discussing improved farm management with farmers. As farmers were not concerned with the uncertainty in the yield estimates, a sensitivity analysis or detailed uncertainty analysis were not relevant.

\subsubsection{First cycle of step 3 (2014)}

During the 2014 dry season, we selected 11 farmers from the core villages (among the 35 farms characterised in detail, see 2.5.1) who had participated in the farmer field day, the feedback session on crop trials and the visit of livestock experiments. With each of these farmers, we conducted an individual farm re-design exercise. Each farmer was asked to imagine a reconfiguration of his farm, i.e. an alternative cropland allocation and/or livestock feeding strategy (considering the 2013 season as the baseline), by including some crop/livestock options he had tested and/or seen during the farmer field day and/or feedback session. For the trade-off analysis we used the average yields and gross margins obtained in the first cycle of Step 2. For groundnut and cotton, which were not included in the 2013 trials, we used average farmerestimated groundnut and average measured (by the Compagnie Malienne pour le Développement des Textiles (CMDT)) cotton yields. During these individual sessions, food self-sufficiency and farm gross margin for the baseline and for the re-designed farm system were calculated and discussed with the farmer based on posters and pictures (Fig. S1). The reconfigurations mentioned by the eleven farmers differed based on the option chosen, the crop replaced, and on whether there was a change or not in livestock feeding strategy. The reconfigurations were grouped into four types, according to similarities in the chosen re-design elements. Eventually, the trade-off analysis was performed for the farms characterised in detail in 2013 using the first reconfiguration type for HRE-LH $(n=5)$ and HRE farms $(n=9$ farms with lactating cows), the second reconfiguration type for MRE farms $(n=7)$, the third reconfiguration type for LRE farms $(n=6)$ and the fourth reconfiguration type for all the farms.

\subsubsection{Second cycle of step 3 (2015)}

In 2015, calendars of oxen requirements for crop activities were built to check the feasibility of the reconfiguration types that were based on cropland expansion. Insights in the causes of yield variability and the niches generated during the second cycle of Step 2 were used to refine the four reconfiguration types and the trade-off analysis was repeated for the farms that had access to these niches. During collective meetings in the core villages, household food self-sufficiency and farm gross margin and other intermediary indicators for the reconfigured farms were discussed with all the 35 participating farmers using posters (Fig. S1). A qualitative assessment of farmers' opinions was based on recorded answers to the open question "What do you think of the differences between the baseline and the re-designed farm system?". 


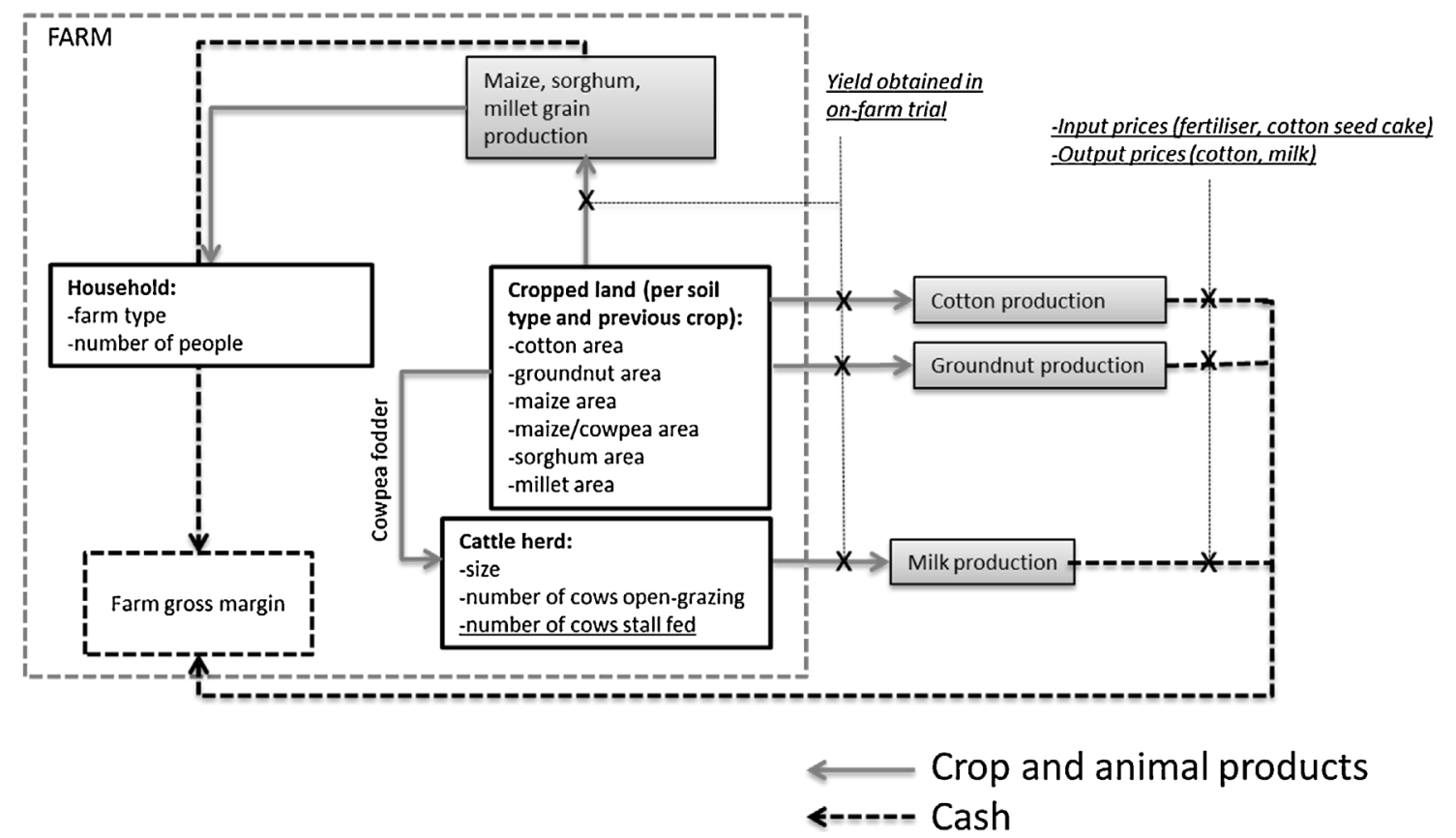

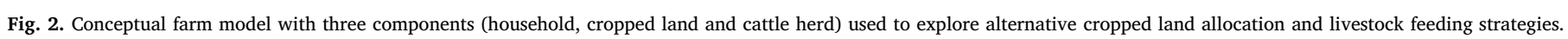

\subsection{Analysis of farmers and researchers learning process}

Farmers' learning was evaluated by taking note of farmers' reactions and analysing their point of view during each step and activity, namely (i) the collective events (field days and workshops for the appraisal of trial results in Step 2, appraisal of re-designed farm systems in Step 3) and (ii) the individual farm re-design exercise in Step 3. The insights gained by researchers when collecting farmers' point of view were assembled to analyse researchers' learning. Eventually, an ex post analysis of the methodological changes that occurred in the different steps allowed to define the project reorientations attributed to the learning in the different steps.

\section{Results}

\subsection{Step 1: design of a set of options based on farmers' constraints and opportunities}

The main constraints to crop production and livestock rearing cited by farmers in all the three villages were lack of oxen, poor soil fertility, animal feeding and animal diseases. Farmers mentioned declining crop yields and gross margins, poor feeding and diseases as the causes for lack of oxen. The final list of options aimed at addressing farmers concerns by increasing yield, farm gross margin and improving livestock feeding and included: (A) intensification of current crops (maize, sorghum and groundnut) with intercropping or the use of improved varieties, mineral fertiliser and manure, (B) diversification with improved varieties of cowpea and soyabean without fertiliser, (C) diversification with improved varieties of cowpea and soyabean with mineral fertiliser, manure and rhizobial inoculation, and (D) improved feeding of lactating cows during the dry hot season with cowpea hay to increase milk production (Table 1). Options related to veterinary care and vaccination that could address the constraint of animal diseases were not included. Farmers' current crops with current cropping practices and cows with current feeding strategy were added as a benchmark (Table 1).

\subsection{First cycle}

\subsubsection{First cycle of step 2}

Assessment of crop trial results showed a wide variation in yields and associated gross margins, regardless of the option, with and without intensification (Fig. 3). For example, grain yield and gross margin of local maize with mineral fertiliser ranged from 0 to $2600 \mathrm{~kg} \mathrm{ha}^{-1}$ and from -130 to $340{\mathrm{US} \$ \text { year }^{-1}}^{-1}$ respectively, while grain yield and gross margin of soyabean ranged from 0 to $1230 \mathrm{~kg} \mathrm{ha}^{-1}$ and from -40 to 920 US\$ year ${ }^{-1}$ respectively. These results, combined with farmers' point of view during the field day, helped researchers to realize that farmers were not so interested in averages and relied on field observations to draw their conclusions (Table 2). This highlighted the need (i) to understand yield and gross margin variability and its relation to farm context and (ii) to refine the focus of the field days in the second cycle towards understanding variability.

Farmers appreciated a large range of options, with some differences among farm types (Table 2). All HRE-LH farmers and a quarter of HRE farmers were positive about intercropping maize with the cowpea fodder variety, mainly because of the production of high-quality fodder for their cattle. The soyabean with no extra input was scored highly by a third of the MRE farmers. These farmers indicated that soybean grain could fetch a high price in the Koutiala market and could replace the seeds of the "Nere" tree (Parkia biglobosa) to prepare the local condiment "Sumbala". The majority of LRE farmers appreciated the cowpea grain variety with $P$ fertiliser and highlighted that cowpea grain could be harvested before other staple crops, thus providing food during the "hunger" period. Sorghum/cowpea intercropping options, hybrid maize without manure and soyabean with inoculum were not rated highly by any farmer.

\subsubsection{First cycle of step 3}

During the individual farm re-design exercises, farmers who had participated in the field visit and feedback session proposed various reconfigurations to re-design their farm system. These reconfigurations were in line with farmers' preferences of options (first cycle of Step 2). All HRE-LH farmers and one HRE farmer were interested in intercropping maize with cowpea (from 30 to $100 \%$ of the maize area) combined 


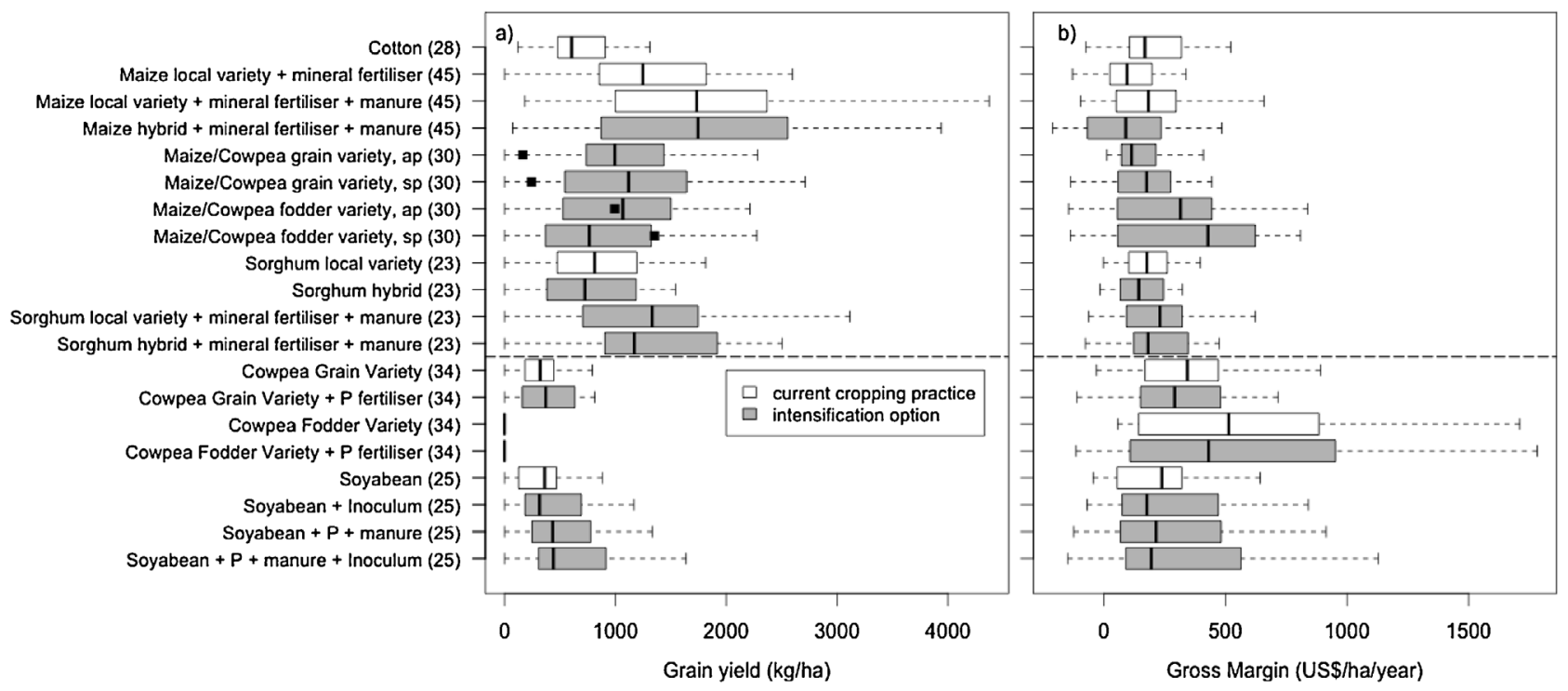

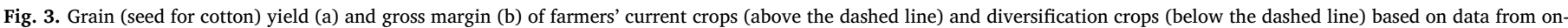

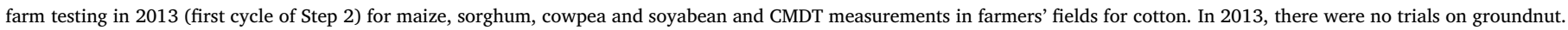
Black dots in a) are cowpea fodder yields. ap = additive pattern, $\mathrm{sp}=$ substitutive pattern. Number of observations in each case is indicated in parenthesis.

with stall feeding of $17-50 \%$ of the lactating cows (Reconfiguration type 1). MRE farmers re-designed their farm system by replacing $20 \%$ of sorghum by soyabean (Reconfiguration type 2). One LRE farmer chose to replace $10 \%$ of sorghum by the cowpea grain variety (Reconfiguration type 3). Two HRE farmers and one LRE farmer considered expanding their cropland (by 10-40\%) with the cowpea fodder and/or grain variety (Reconfiguration type 4). The ex-ante trade-off analysis showed different outcomes for each farm type. Without compromising food self-sufficiency, (i) HRE-LH could intercrop $80 \%$ of maize with cowpea, allowing to feed $74 \%$ of lactating cows in the stall and leading to a $12 \%$ increase in farm gross margin (i.e. a 236 US\$ year $^{-1}$ absolute increase), (ii) MRE farms could replace $60 \%$ of sorghum by soyabean leading to a $18 \%$ increase in farm gross margin (i.e. a 184 US\$ year ${ }^{-1}$ absolute increase). Due to the strong maize yield penalty related to intercropping, HRE farms could not intercrop maize with cowpea without compromising food self-sufficiency. Because of their small initial level of food self-sufficiency, LRE farms could not replace sorghum by cowpea grain. Eventually, Reconfiguration type 4 always increased farm gross margin.

All 11 farmers that participated in the exercise considered the farm gross margin improvement to be a promising outcome. HRE-LH and HRE farmers were concerned by the $5 \%$ average decrease in food selfsufficiency due to the penalty to maize grain in intercropping. MRE farms were disappointed by the small absolute gross margin increase from Reconfiguration type 3 (184 US\$ year ${ }^{-1}$ ), which could not allow them to buy an ox (435 US\$). Though farmers were disappointed, they liked the exercise and mentioned that they learned how to plan cereal production and sales to fulfil household needs (Table 2). Farmers expressed their concern about the limited availability of oxen that would impede the cropland expansion of Reconfiguration type 4 (Table 2). Subsequently, researchers realized the importance of oxen availability for crop activities and the need to assess oxen labour calendars to check the feasibility of land expansion (Table 2).

\subsection{Second cycle}

\subsubsection{Second cycle of step 2}

During the field day in 2014, farmers indicated that the soil type and the previous crop in the rotation could explain yield variability in the control plots (Table 2). The statistical analysis confirmed farmers' perception and showed that (i) maize, soyabean and groundnut grain yields and maize partial Land Equivalent Ratio (pLER) in intercropping were higher after cotton and maize (the fertilised crops) compared with after sorghum or millet (the un-fertilised crops), (ii) sorghum and soyabean grain yields and cowpea fodder yields were greater on black soils compared with sandy and gravelly soils. Due to pest attacks, cowpea grain yields were not affected by soil type (see Falconnier et al. (2016) for more detailed results). As a result, researchers defined niches based on soil type and previous crop (Table 2), where diversification with legumes without extra input yielded best results (Fig. 4). Without fertiliser, soyabean gross margin was $110 \%$ greater than the gross margin of the local sorghum variety without fertiliser (farmer practice) on black soils, provided that the previous crop was cotton or maize, whereas it was only $20 \%$ greater and $35 \%$ smaller on sandy and gravelly soils respectively (Fig. 4a). Conversely, cowpea gross margin was only $41 \%$ greater than local sorghum gross margin on black soils (Fig. 4b) but 140 and $86 \%$ greater on gravelly and sandy soils respectively (regardless of the previous crop, which did not affect cowpea yields). Furthermore, the difference in grain yield between cowpea and sorghum was smaller on gravelly and sandy soils compared with black soils. Maize/cowpea intercropping after cotton and maize with the additive pattern resulted in no maize grain yield penalty compared with sole cropping (average maize pLER $=1.07$ ) and extra fodder production $\left(1390 \mathrm{~kg} \mathrm{ha}^{-1}\right.$ on average, with cowpea pLER $\left.=0.4\right)$ (Fig. 4c).

Most of the intensification options on current crops and diversification crops had a Benefit:Cost ratio less than two and/or a probability of generating profit of less than 0.5. However, the soybean option with manure and $\mathrm{P}$ fertiliser, the cowpea option with $\mathrm{P}$ fertiliser and the groundnut improved variety had Benefit:Cost ratios higher than two and probabilities of generating profit larger than 0.5 (Fig. 5a). The intercropping options with maize and cowpea showed large Benefit:Cost ratios and the probability of generating a profit was always larger than 0.5 (Fig. 5b). Interestingly, farmers considered the entire range of Benefit:Cost ratios to decide on their treatment preference. When discussing the hybrid maize variety for example, farmers mentioned "There are too many people who failed to generate profit" and "There is no point in buying improved seed if the benefit achieved by the best farmer is so low". This discussion highlighted the fact that risk perception was an important factor affecting farmers' choices. The niche information that allows increasing the probability of a positive effect of an option was therefore integrated in the ex-ante analysis of Step 3 (Table 2). 


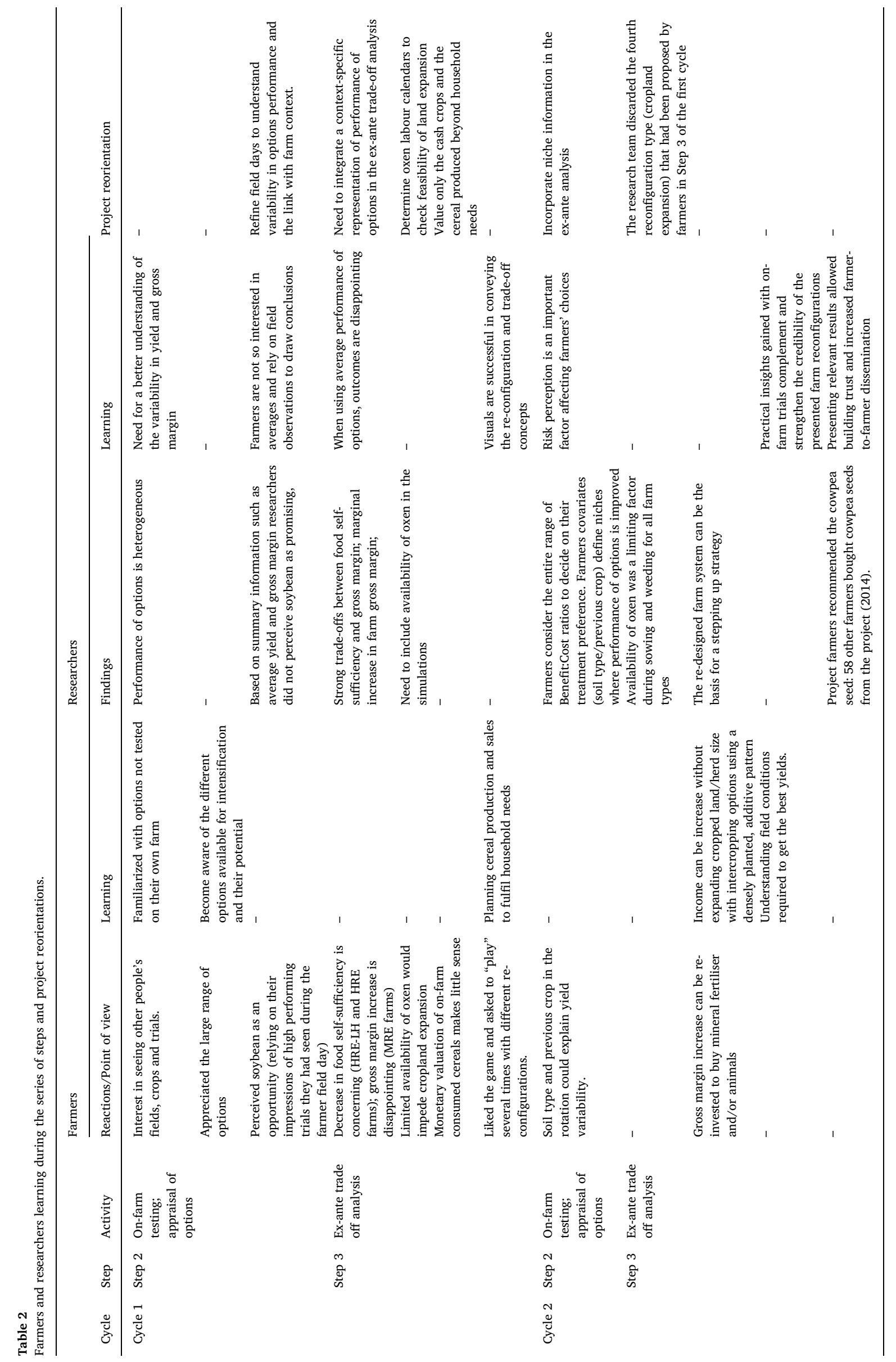



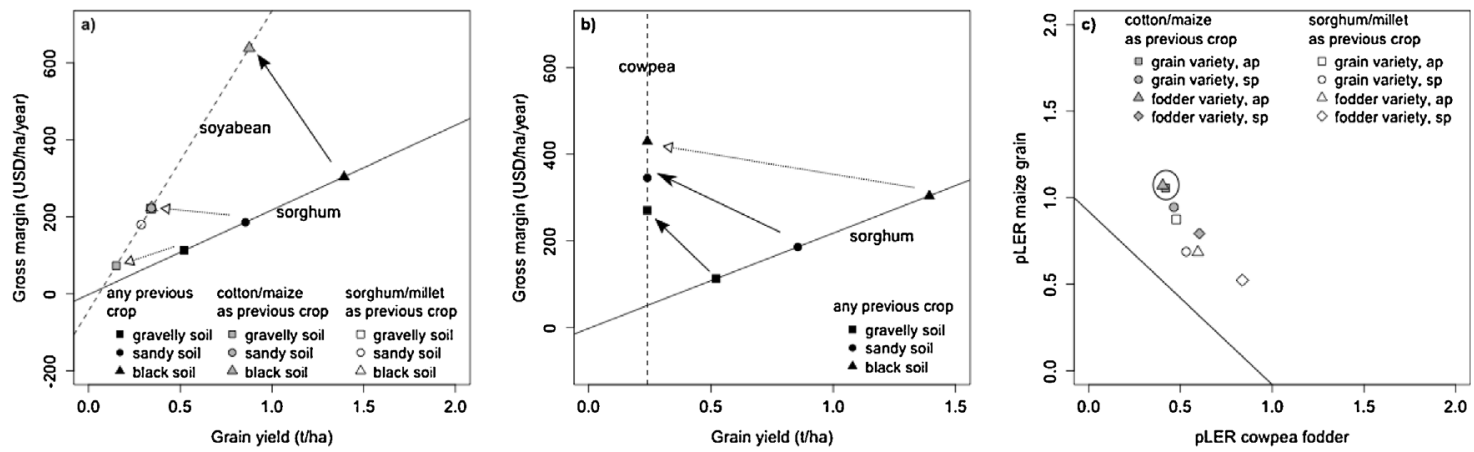

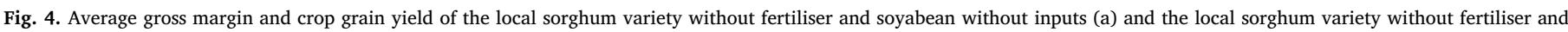

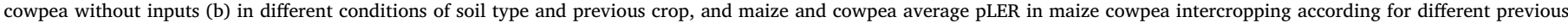

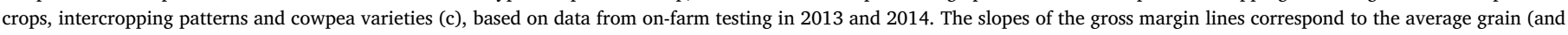

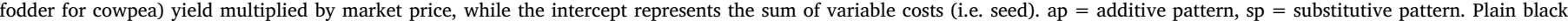

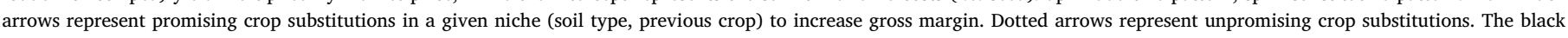
circle in c) represents a promising combination of pattern, variety and previous crop to produce fodder without a penalty to maize production.

\subsubsection{Second cycle of step 3}

The oxen-day requirement calendar showed that availability of oxen was a limiting factor during sowing and weeding for all farm types. Therefore the research team discarded the fourth reconfiguration type (cropland expansion) that had been proposed by farmers in Step 3 of the first cycle. Using the information on the niches identified during Step 2 of the second cycle, the refined reconfigurations included: maize intercropped with cowpea only after cotton or maize (refined Reconfiguration type 1), sorghum replaced by soyabean only on black soils after cotton or maize (refined Reconfiguration type 2), and sorghum replaced by cowpea only on sandy and gravelly soils (refined Reconfiguration type 3). Ex ante analysis of the re-designed farm systems with the refined reconfigurations suggested that without compromising food self-sufficiency i) HRE-LH farms could intercrop all of their maize after cotton with cowpea, allowing on average $93 \%$ of lactating cows to be fed in the stall and leading to a $20 \%$ increase in average whole farm gross margin (690 US\$ year ${ }^{-1}$ ) (Fig. 6), ii) HRE farms could intercrop all of their maize after cotton with cowpea, allowing on average $92 \%$ of lactating cows to be fed in the stall and leading to a $26 \%$ increase in average farm gross margin (453 US\$ year $^{-1}$ ) (Fig. 6), iii) MRE farms could replace $80 \%$ of sorghum on black soils after cotton or maize by soyabean leading to a $29 \%$ increase in farm gross margin (545 US\$ year ${ }^{-1}$ ) (Fig. 7), iv) LRE farms could replace $20 \%$ of sorghum on sandy and gravelly soils by cowpea grain variety, leading to a $9 \%$ increase in farm gross margin (32 US\$ year ${ }^{-1}$ ) (Fig. 7). Farmers' evaluations of the re-designed farm system indicated that the gross margin increase appeared significant to them and that it could be re-invested in the farm to buy mineral fertiliser and/or animals (Table 2).

\subsection{Learning processes and project reorientations}

Famers' reaction and point of view in the different cycles and steps complemented researchers' findings and allowed project reorientation (Table 2). Researchers' understanding of farmers' perception and of farm system functioning increased in each successive cycle, resulting in a refined assessment of options and farm reconfigurations. Farmers' learning was in the first cycle linked to practical/technical considerations (e.g. discovering new technical options, planning cereal sales). It evolved in the second cycle from practical to more profound learning
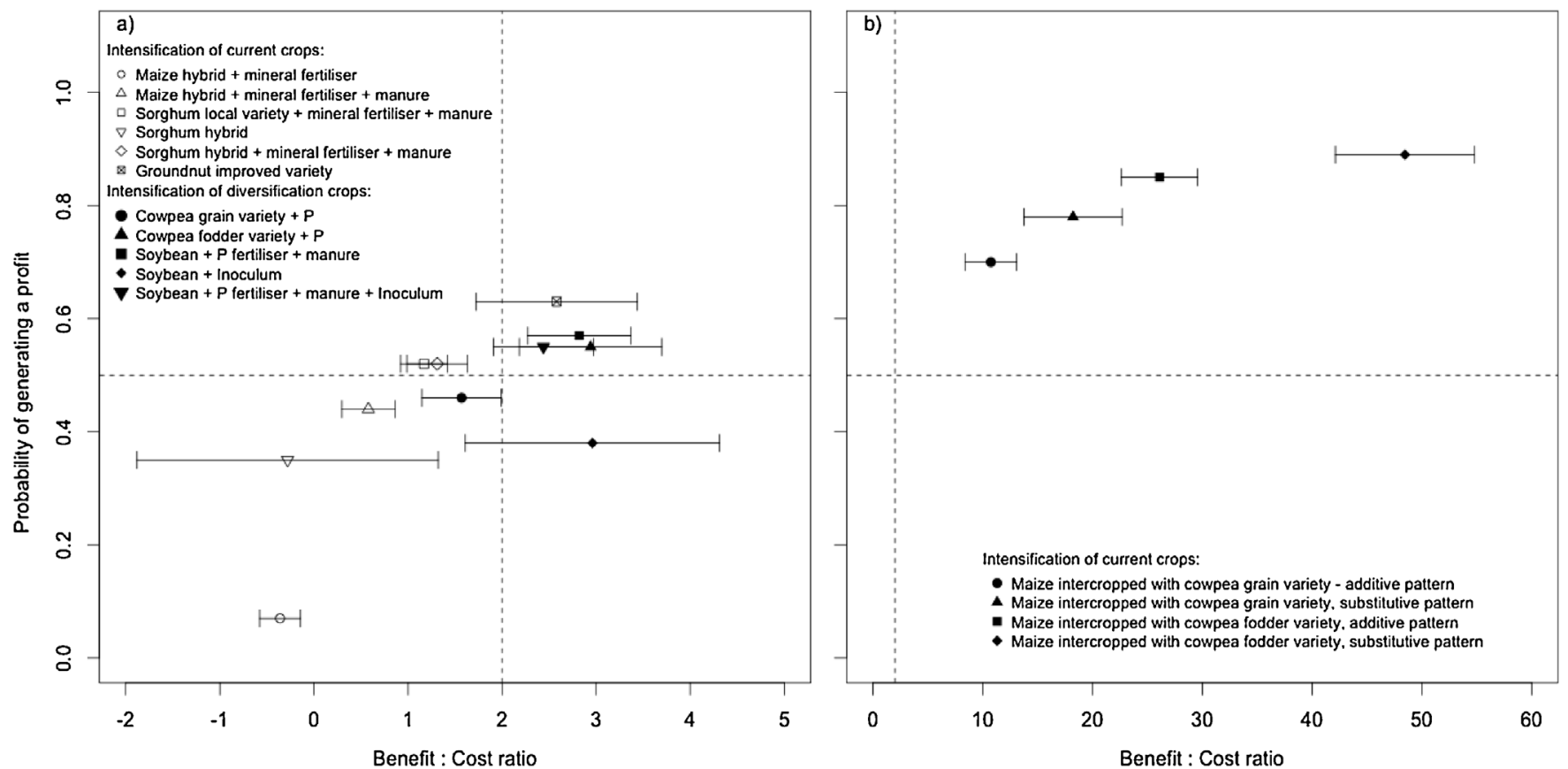

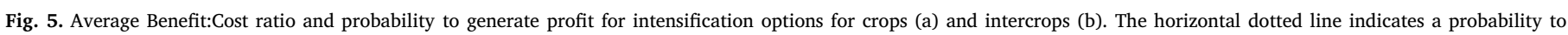
generate profit of 0.5 , the vertical dotted line indicates a Benefit:Cost ratio of two. Bars indicate the standard error of the mean for Benefit:Cost ratio. 


\section{HRE-LH}
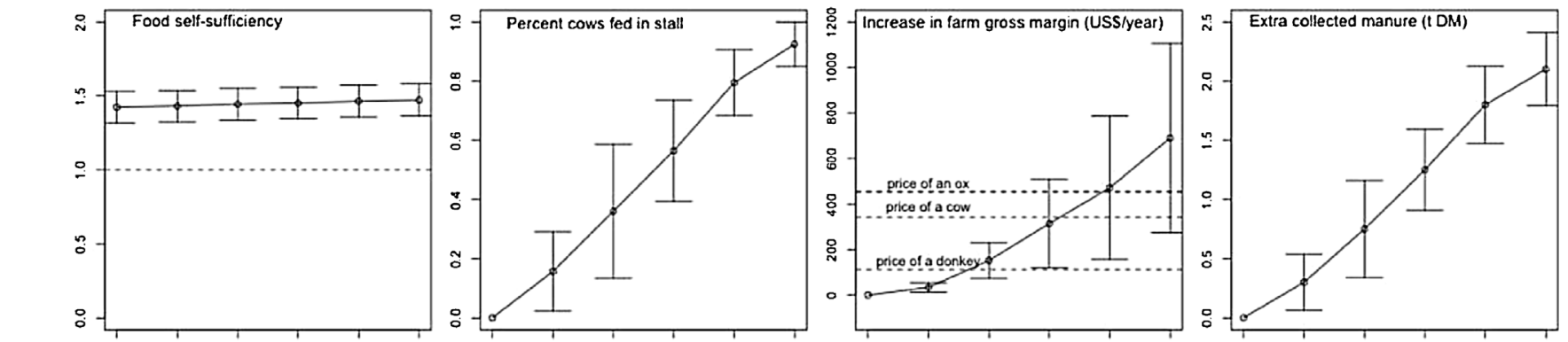

HRE
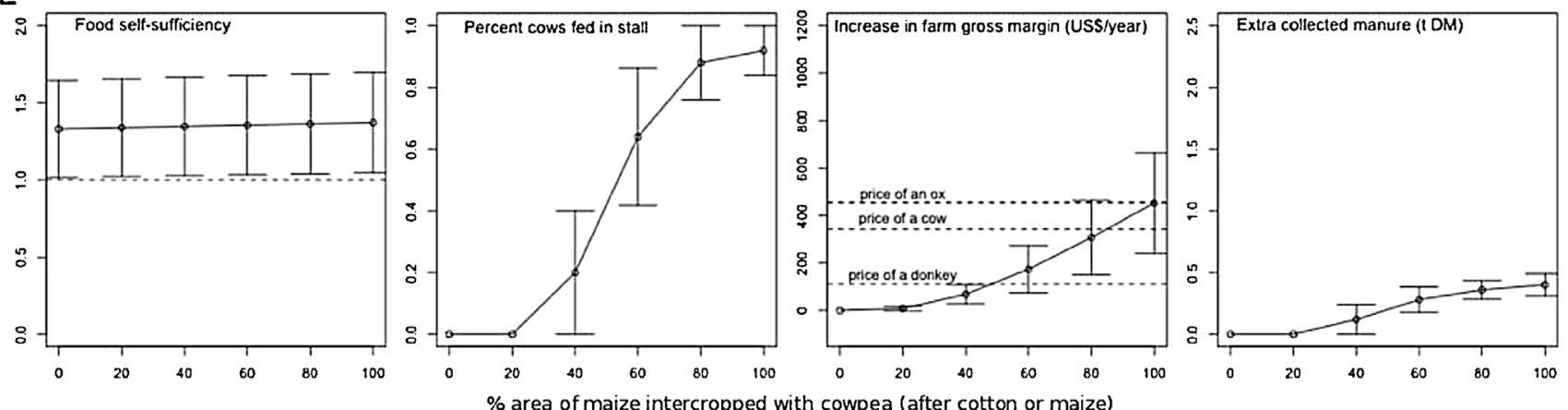

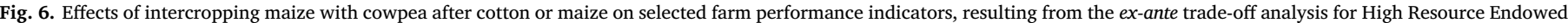

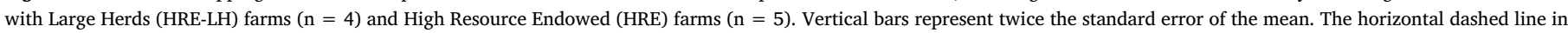
the "Food self-sufficiency" plots represents the food self-sufficiency threshold of one, meaning all household energy needs are provided by the household's own cereal production.

\section{MRE}

\section{LRE}
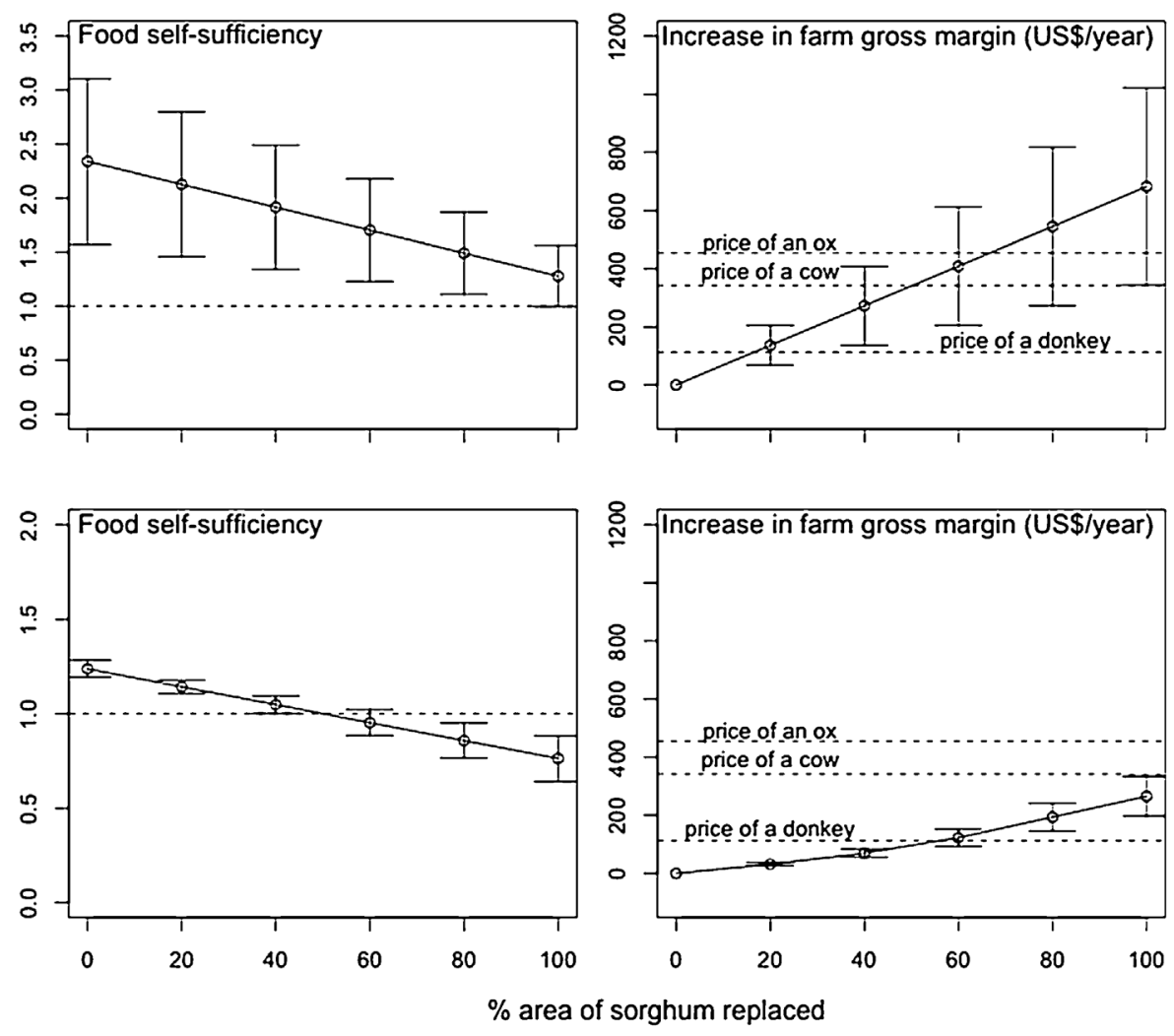

Fig. 7. Effects of replacing sorghum on selected farm performance indicators, resulting from the ex-ante trade-off analysis for Medium Resource Endowed (MRE) farms $(n=2)$ and Low Resource Endowed (LRE) farms $(n=4)$. For MRE farms, sorghum is replaced by soyabean on black soils after cotton and maize, for LRE farms sorghum is replaced by cowpea grain variety on gravelly or sandy soils. Vertical bars represent twice the standard error of the mean. The horizontal dashed line in the "Food self-sufficiency" plots represents the food self-sufficiency threshold of one, meaning all household energy needs are provided by the household's own cereal production. 
and allowed them to revise their initial assumption that farm gross margin could not be increased without land expansion (Table 2).

\section{Discussion}

\subsection{Research adaptation is a key feature of the DEED cycle}

Performing two iterations of the DEED cycle allowed integrating generated knowledge into the research process, thus enabling the agile reorientation of project actions and increasing the chances to design promising and relevant alternatives (López-Ridaura et al., 2002; Mierlo et al., 2010; Rossing et al., 1997). In this research, farmers' reaction and point of view in the different cycles and steps complemented researchers' findings, thus triggering project reorientation (Table 2). After the first cycle of on-farm trials, researchers did not perceive soyabean as promising, because they relied on summary information such as average yield and gross margin. Conversely, some farmers perceived it as an opportunity and included it in the reconfiguration of their farms, because they relied on their impressions of high performing trials witnessed during the farmer field day (Table 2). This different way of understanding and interpreting field experiments highlighted the difference in "world views" between farmers and researchers (Sumberg et al., 2003). Also during the second cycle, farmers' indigenous knowledge and researchers' statistical analysis complemented each other, resulting in a shared and credible explanation for yield variability (Fig. 4).

The adaptive nature of our approach was a key element not only for enabling convergent learning (Mierlo et al., 2010), but also for the generation of promising designs, relevant for different farm types. During the first DEED cycle, the farm reconfigurations with the options chosen by farmers performed poorly in terms of either strong trade-offs between food self-sufficiency and gross margin, or the marginal increase in farm gross margin. These disappointing results were mainly due to poor average yield and gross margin of some options (Fig. 3). As such, the first DEED cycle identified knowledge gaps and pinpointed to the need for a better understanding of yield and gross margin variability. This realisation was crucial for the second cycle, in which the farmer field day and the analysis of trial results were refined. The $e x-$ ante analysis was adapted, based on the incorporation of farmers' knowledge and a context-specific representation of the performance of options (Table 2). This led to more promising re-designed farm systems after the second cycle (Figs. 6 and 7). While we did not measure effective adoption and implementation by farmers of the explored farm reconfiguration, we already witnessed examples of farmer to farmer dissemination (Table 2).

\subsection{Salient, legitimate and credible guidelines}

The knowledge generated through our PLAR can be translated into boundary objects, i.e. "methods of common communication across dispersed work groups" (Star and Griesemer, 1989), because it can be seen as a set of guidelines to inform the discussions between farmers and extension workers. For a given farmer, this set of guidelines would be based on: (i) the characterisation of the farm type based on simple resource endowment indicators, e.g. household size, livestock, total cropped land (Falconnier et al., 2015) (ii) the choice of an option suitable for that farm type, i.e. cowpea for LRE farms, soyabean for MRE farms and maize/cowpea for HRE-LH and HRE farms, (iii) the identification of the niche where this option performs best, based on the local knowledge of soil type and previous crops (Fig. 4) and (iv) setting the maximum percentage of crop replacement without compromising food self-sufficiency.

For effective translation of knowledge into action, boundary objects must meet the saliency, credibility and legitimacy criteria (Cash et al., 2003). Saliency was built up throughout our design process: the generated knowledge was based on farmers' descriptions of constraints and opportunities, exploration of farm reconfigurations imagined by farmers, farmers' understanding of yield variability, and farmers' collective appraisal of the re-designed farm systems (Table 2). Saliency was further ensured by encompassing both crops and livestock activities and thus representing the complexity of farmers' management (Martin, 2015), and by taking into account risk.

The credibility of the generated knowledge was guaranteed by (i) a robust research design, i.e. measurements in more than 340 trials during two growing season, and (ii) the use of linear mixed effect models (Falconnier et al., 2016) to explain variability in crop yield and to support the qualitative insights obtained through trial visits and farmers' appraisals.

Legitimacy was ensured by the participation of farmers with different resource endowment and production objectives, so that the diversity of farmers' knowledge, interests and perspectives could be taken into account. Farmers choice in terms of farm re-configuration was consistent within a given farm type, illustrating the fact that our typology, integrating food self-sufficiency (Falconnier et al., 2015) and livestock holding, was relevant to understand the choice made by farmers. In Farmer Field Schools, experimentation is often done with an existing farmer group within the community (de Jager et al., 2009), and some types of households may be overlooked. In our approach, we purposively invited LRE farmers to join the activities, as they were not part of the existing community groups. Our approach combined individual actions (interviews, farm re-design exercises) with collective ones (feedback and appraisal sessions). On the one hand, this allowed for discussion and validation of individual farmers' perceptions in wider groups. On the other hand, with individual interviews we collected information that shy farmers would not share in a wider assembly. This combination however has limits as dominant personalities may influence group responses and their views might be over-emphasized (Gill et al., 2008).

By ensuring saliency, credibility and legitimacy, our study overcame common pitfalls of top-down research, namely: a focus on better-off farmers at the expense of the less endowed (Degnbol, 2001); the generation of simple and standardized technical recommendations (Okali et al., 1994); and a lack of credibility (Van Asten et al., 2009).

\subsection{Opportunities for scaling-out}

In this section we describe how both the set of guidelines described above and the cyclic approach can be scaled out.

The set of guidelines identified holds for an area broader than the nine villages where it has been generated. The "old cotton basin", an area situated in the Sudanian agro-ecological zone (Coulibaly, 2003), groups the districts of Koutiala and Dioila and the northern part of the Sikasso district and comprises more than a million of rural people (Traore et al., 2011). This area is characterized by cotton/cereal rotation with use of manure and mineral fertiliser, draught power by oxen, credit for inputs and guaranteed purchase of cotton by the CMDT (Soumaré et al., 2008; Tumusiime et al., 2014). With a biophysical and socio-economic environment similar to the nine study villages, the guidelines generated could be applied throughout this "old cotton basin". The non-governmental organisation AMEDD was a key partner in this research, and their involvement in extension activities offers the potential to expand the number of beneficiaries (Hellin et al., 2008; Okali et al., 1994). This out-scaling potential can lead to a better costeffectiveness compared with an approach that would produce knowledge that is very site-specific and cannot be used by a larger number of beneficiaries (Rusike et al., 2006; Snapp et al., 2002).

Furthermore, the approach of adaptive research cycles can be reproduced with a different set of options and/or in another environment. Farmers' understanding of yield variability could be incorporated from the start of the experiments, thus allowing faster progress in the design of successful alternatives. Similarly to other participatory approaches (Defoer, 2002; Schaap et al., 2013), our approach can be scaled-out to 
facilitate learning by farmers, extension workers and researchers, and offers an alternative to the current linear and unidirectional (researcher-extension-farmer) Transfer of Technology and Training and Visits approaches in southern Mali (Degnbol, 2001; Heemskerk et al., 2008). In order to realize this out-scaling potential, the role of the extension worker has to move from technology transfer to "problem solving" (Ramirez, 1997). In order to deliver a complex and nuanced message adapted to the different farm categories, extension workers are likely to require capacity building to improve their interdisciplinary skills (Cundill et al., 2012). Fragmentation of current extension services adds to this challenge: e.g. CMDT extension oversees cotton-related issues, but operates separately from livestock services (Degnbol, 2001; Heemskerk et al., 2008), while interactions between the crop and livestock components influence to a large extent the functioning of the current farm systems.

\subsection{Farm reconfiguration for sustainable intensification?}

The farm reconfigurations inspired farmers to imagine "stepping up" strategies (Dorward et al., 2009; Falconnier et al., 2015) over a longer term. Farmers suggested that the extra income could be reinvested to buy livestock and/or fertiliser (Table 2), highlighting the opportunities to climb the livestock and agricultural intensification ladder (Aune and Bationo, 2008; Udo et al., 2011). Farm resource endowment determines the achievable improvements: LRE farmers would need to buy a donkey the first year and a cart in the second year to carry compost and fertilise crops, thus increasing yields and income, which could be in turn used to buy a goat or a calf (Fig. 7). The other farm types can climb the ladder faster as the income increase related to the farm reconfigurations would allow them to buy a cow or an ox, without endangering food self-sufficiency (Figs. 6 and 7). This increase in stock would have to go hand in hand with an increase in overall biomass production to counter the increased pressure on feed resources like crop residues (McDermott et al., 2010). Production of cowpea fodder and stall feeding of lactating cows appears profitable for HRE-LH and HRE farms and can trigger positive feedbacks with the extra manure collected in the stall (Fig. 6). Some farms without access to the identified niches (e.g. dark soils) may however not be able to apply these "stepping up" strategies.

Constraints at the level beyond the farm currently prevent many farmers for moving towards the innovative farm systems we assessed and discussed with them. In what follows we highlight the necessary changes to remove those barriers. The wide adoption of farm reconfigurations based on stall feeding is currently impeded by the poorly developed milk sector. Broader institutional change would be needed to improve the availability of cowpea seeds, reduce powder milk imports in favour of local milk (Corniaux et al., 2012), and to develop roads and infrastructure. Although diversification with legumes offers potential, cotton remains a key feature of the current farming system. Access to subsidised fertiliser for cotton and maize is guaranteed by the CMDT, and the nutrients carried-over benefit the following crops (Falconnier et al., 2016; Ripoche et al., 2015). This carry-over is the backbone of the niches identified for maize/cowpea intercropping and soyabean production (Fig. 4) (Falconnier et al., 2016). As the maintenance of a functional cotton sector is uncertain due to world price fluctuations (Coulibaly et al., 2015; Falconnier et al., 2015), the viability of the farm reconfigurations depends on the development of sustainable alternatives. With a large Cost:Benefit ratio and a low risk for farmers, soyabean with manure and P fertiliser (Fig. 5) could partially replace cotton as a cash crop at the start of the rotations. The increase in the demand for livestock products in the cities in Mali and across West Africa and the expected growth in urban poultry production (Amadou et al., 2012) offer opportunities for the development of a soyabean value chain for poultry feed. Plausible futures can be explored using scenarios that cover a range of socioeconomic and biophysical conditions and can therefore inform decision-making and targeting of agricultural development investments. Considering farm heterogeneity and changes in entire farm populations is crucial in such scenario analyses to identify and direct effective efforts towards sustainable intensification (Falconnier et al., submitted).

\section{Conclusion}

Over a period of three years researchers, development agents and farmers experimented together a wide array of technical options related to crops and livestock and explored farm reconfigurations with promising options. Two experimental cycles led to convergent learning and project reorientation: farmers and researchers were able to share a common understanding of yield variability based on local knowledge and statistical analysis of the trials. The first cycle revealed strong trade-offs between food self-sufficiency and farm income and/or small gross margin increases linked to diversification with legume crops. The knowledge generated during the second cycle allowed defining niches (i.e. particular biophysical conditions constituted by soil type and previous crop) for diversification with legumes. Incorporating the niche information in the ex-ante analysis during the second cycle allowed alleviating some of the trade-offs and achieving more promising farm reconfigurations. These farm reconfigurations increased farm gross margin without compromising food self-sufficiency, based on simple guidelines like farm type, soil type and position in the rotation. Local NGOs and extension agencies can now use these simple guidelines to reach a larger number of beneficiaries in areas with an environment similar to the study villages. Further, the research approach is scalable to other environments, where it can trigger learning among stakeholders, and integration of farmers understanding at the very start of the experiments can speed up the re-design process. The farm reconfigurations are promising pathways for both crop and livestock intensification and farms can 'step up' to higher levels of productivity. Development of sustainable alternatives to cotton production with stronger support to milk and soyabean production will be needed to trigger adoption of these reconfigurations by a large number of farmers.

\section{Acknowledgements}

Funding for this study was provided by the McKnight Foundation through the project 'Pathways to Agro-ecological Intensification of Sorghum and Millet Cropping Systems of Southern Mali' and by the CGIAR Research Program on Dryland Systems. We thank all the farmers of M'Peresso, Nampossela, Nitabougouro, N'Goukan, Finkoloni, Kani, Karangasso, Koumbri and Try for their availability and willingness to participate in the research process. We are grateful to the Association Malienne d'Eveil au Développement Durable (AMEDD), Ousmane Dembele, Michel Sagara, Bakary Dao, Moumine Toure, Abdoulaye Dembele, Soungalo Bware and several trainees who assisted in data collection. We thank the Institut d'Economie Rurale (IER), Ousmane Sanogo, Salif Doumbia and N'Golo Coulibaly who assisted with the livestock experiments. Thanks also to two reviewers for their detailed comments that helped us to improve the manuscript.

\section{Appendix A. Supplementary data}

Supplementary data associated with this article can be found, in the online version, at http://dx.doi.org/10.1016/j.eja.2017.06.008.

\section{References}

Amadou, H., Dossa, L.H., Lompo, D.J.-P., Abdulkadir, A., Schlecht, E., 2012. A comparison between urban livestock production strategies in Burkina Faso, Mali and Nigeria in West Africa. Trop. Anim. Health Prod. 44, 1631-1642. http://dx.doi.org/10.1007/ s11250-012-0118-0.

Andrieu, N., Dugue, P., Le Gal, P.-Y., Rueff, M., Schaller, N., Sempore, A., 2012. Validating a whole farm modelling with stakeholders: evidence from a West African case. J. Agric. Sci. 4. http://dx.doi.org/10.5539/jas.v4n9p159. 
Aune, J.B., Bationo, A., 2008. Agricultural intensification in the Sahel - the ladder approach. Agric. Syst. 98, 119-125. http://dx.doi.org/10.1016/j.agsy.2008.05.002.

Autfray, P., Sissoko, F., Falconnier, G., Ba, A., Dugué, P., 2012. Usages des résidus de récolte et gestion intégrée de la fertilité des sols dans les systèmes de polyculture élevage: étude de cas au Mali-Sud. Cah. Agric. 21, 225-234. http://dx.doi.org/10. 1684/agr.2012.0568.

Bielders, C.L., Gérard, B., 2015. Millet response to microdose fertilization in south-western Niger: effect of antecedent fertility management and environmental factors. Field Crops Res. 171, 165-175. http://dx.doi.org/10.1016/j.fcr.2014.10.008.

Bosma, R., Bos, M., Kanté, S., Kébé, D., Quak, W., 1999. The promising impact of ley introduction and herd expansion on soil organic matter content in southern Mali. Agric. Syst. 62, 1-15. http://dx.doi.org/10.1016/S0308-521X(99)00038-4.

Cash, D.W., Clark, W.C., Alcock, F., Dickson, N.M., Eckley, N., Guston, D.H., Jäger, J., Mitchell, R.B., 2003. Knowledge systems for sustainable development. Proc. Natl. Acad. Sci. 100, 8086-8091. http://dx.doi.org/10.1073/pnas.1231332100.

Chopin, P., Blazy, J.-M., Doré, T., 2014. A new method to assess farming system evolution at the landscape scale. Agron. Sustain. Dev. 35, 325-337. http://dx.doi.org/10.1007/ s13593-014-0250-5.

Corniaux, C., Vatin, F., Ancey, V., 2012. Lait en poudre importé versus production locale en Afrique de l'Ouest: vers un nouveau modèle industriel? Cah. Agric. 21, 18-24. http://dx.doi.org/10.1684/agr.2012.0536.

Coulibaly, J.Y., Sanders, J.H., Preckel, P.V., Baker, T.G., 2015. Will cotton make a comeback in Mali? Agric. Econ. 46, 53-67. http://dx.doi.org/10.1111/agec.12140.

Coulibaly, A., 2003. Country Pasture and Forage Resources Profiles. FAO, Rome. http:// www.fao.org/ag/agp/agpc/doc/counprof/PDF\%20files/Mali-English.pdf.

Cundill, G., Cumming, G.S., Biggs, D., Fabricius, C., 2012. Soft systems thinking and social learning for adaptive management. Conserv. Biol. 26, 13-20. http://dx.doi.org/10. 1111/j.1523-1739.2011.01755.x.

De Ridder, N., Sanogo, O.M., Rufino, M.C., van Keulen, H., Giller, K.E., 2015. Milk: the new white gold? Milk production options for smallholder farmers in Southern Mali. Animal 1-9. http://dx.doi.org/10.1017/s1751731115000178.

Defoer, T., 2002. Learning about methodology development for integrated soil fertility management. Agric. Syst. 73, 57-81. http://dx.doi.org/10.1016/S0308-521X(01) 00100-7.

Degnbol, T., 2001. Inside government extension agencies: a comparison of four agencies in the Sikasso Region of Mali. In: Benjaminsen, T.A., Lund, C. (Eds.), Politics, Property and Production in the West African Sahel: Understanding Natural Resources Management. Nordic Africa Institute, pp. 100-116.

Descheemaeker, K., Oosting, S.J., Tui, S.H.-K., Masikati, P., Falconnier, G.N., Giller, K.E., 2016a. Climate change adaptation and mitigation in smallholder crop-livestock systems in sub-Saharan Africa: a call for integrated impact assessments. Reg. Environ. Change 16, 2331-2343. http://dx.doi.org/10.1007/s10113-016-0957-8.

Descheemaeker, K., Ronner, E., Ollenburger, M., Franke, A.C., Klapwijk, C.J., Falconnier, G.N., Wichern, J., Giller, K.E., 2016b. Which options fit best? Operationalizing the socio-ecological niche concept. Exp. Agric. 1-22. http://dx.doi.org/10.1017/ s001447971600048x.

Dogliotti, S., García, M.C., Peluffo, S., Dieste, J.P., Pedemonte, A.J., Bacigalupe, G.F., Scarlato, M., Alliaume, F., Alvarez, J., Chiappe, M., Rossing, W.A.H., 2014. Co-innovation of family farm systems: a systems approach to sustainable agriculture. Agric. Syst. 126, 76-86. http://dx.doi.org/10.1016/j.agsy.2013.02.009.

Dorward, P., Galpin, M., Shepherd, D., 2003. Participatory farm management methods for assessing the suitability of potential innovations. A case study on green manuring options for tomato producers in Ghana. Agric. Syst. 75, 97-117. http://dx.doi.org/ 10.1016/S0308-521X(02)00034-3.

Dorward, A., Anderson, S., Nava, Y., Pattison, J., Paz, R., Rushton, J., Sanchez Vera, E., 2009. Hanging In, stepping up and stepping out: livelihood asspirations and strategies of the Poor. Dev. Pract. 19, 240-247.

Ebanyat, P., de Ridder, N., de Jager, A., Delve, R.J., Bekunda, M.A., Giller, K.E., 2010. Drivers of land use change and household determinants of sustainability in smallholder farming systems of Eastern Uganda. Popul. Environ. 31, 474-506. http://dx doi.org/10.1007/s11111-010-0104-2.

Falconnier, G.N., Descheemaeker, K., Van Mourik, T.A., Sanogo, O.M., Giller, K.E., 2015. Understanding farm trajectories and development pathways: two decades of change in southern Mali. Agric. Syst. 139, 210-222. http://dx.doi.org/10.1016/j.agsy.2015. 07.005 .

Falconnier, G.N., Descheemaeker, K., Van Mourik, T.A., Giller, K.E., 2016. Unravelling the causes of variability in crop yields and treatment responses for better tailoring of options for sustainable intensification in southern Mali. Field Crops Res. 187, 113-126. http://dx.doi.org/10.1016/j.fcr.2015.12.015.

G.N. Falconnier, K. Descheemaeker, B. Traore, A. Bayoko, K.E. Giller, Agricultural intensification and policy interventions: exploring plausible futures for smallholder farmers in Southern Mali. Submitted to Land Use Policy, submitted.

Gill, P., Stewart, K., Treasure, E., Chadwick, B., 2008. Methods of data collection in qualitative research: interviews and focus groups. Br. Dent. J. 204, 291-295. http:// dx.doi.org/10.1038/bdj.2008.192.

Giller, K.E., Tittonell, P., Rufino, M.C., van Wijk, M.T., Zingore, S., Mapfumo, P., AdjeiNsiah, S., Herrero, M., Chikowo, R., Corbeels, M., Rowe, E.C., Baijukya, F., Mwijage, A., Smith, J., Yeboah, E., van der Burg, W.J., Sanogo, O.M., Misiko, M., de Ridder, N., Karanja, S., Kaizzi, C., K'ungu, J., Mwale, M., Nwaga, D., Pacini, C., Vanlauwe, B., 2011. Communicating complexity: integrated assessment of trade-offs concerning soil fertility management within African farming systems to support innovation and development. Agric. Syst. 104, 191-203. http://dx.doi.org/10.1016/j.agsy.2010.07. 002.

Heemskerk, W., Nederlof, S., Wennink, B., 2008. Outsourcing Agricultural Advisory Services. KIT, Amsterdam.

Hellin, J., Bellon, M.R., Badstue, L., Dixon, J., La Rovere, R., 2008. Increasing the impact of participatory research. Exp. Agric. 44, 81-95. http://dx.doi.org/10.1017/ S0014479707005935.

Kaminski, J., Elbehri, A., Samake, M., 2013. An assessment of sorghum and millet in Mali and implications for competitive and inclusive value chains. In: Elbehri, A. (Ed.), Rebuilding West Africa's Food Potential: Policies and Market Incentives for Smallholder-Inclusive Food Value Chains. FAO/IFAD, Rome, pp. 481-500.

Kanté, S., 2001. Gestion de la fertilité des sols par classe d'exploitation au Mali-Sud. PhD Thesis. Wageningen University, Wageningen.

López-Ridaura, S., Masera, O., Astier, M., 2002. Evaluating the sustainability of complex socio-environmental systems. the MESMIS framework. Ecol. Indic. 2, 135-148. http://dx.doi.org/10.1016/S1470-160X(02)00043-2.

Le Gal, P.-Y., Merot, A., Moulin, C.-H., Navarrete, M., Wery, J., 2010. A modelling framework to support farmers in designing agricultural production systems. Environ. Model. Softw. 25, 258-268. http://dx.doi.org/10.1016/j.envsoft.2008.12.013.

Le Gal, P.-Y., Dugué, P., Faure, G., Novak, S., 2011. How does research address the design of innovative agricultural production systems at the farm level? A review. Agric. Syst. 104, 714-728. http://dx.doi.org/10.1016/j.agsy.2011.07.007.

Losch, B., Fréguin-Gresh, S., White, E.T., 2012. Structural Transformation and Rural Change Revisited: Challenges for Late Developing Countries in a Globalizing World. World Bank, Washington, DC.

Martin, G., Martin-Clouaire, R., Duru, M., 2012. Farming system design to feed the changing world. A review. Agron. Sustain. Dev. 33, 131-149. http://dx.doi.org/10. 1007/s13593-011-0075-4.

Martin, G., 2015. A conceptual framework to support adaptation of farming systems development and application with Forage Rummy. Agric. Syst. 132, 52-61. http:// dx.doi.org/10.1016/j.agsy.2014.08.013.

McDermott, J.J., Staal, S.J., Freeman, H.A., Herrero, M., Van de Steeg, J.A., 2010. Sustaining intensification of smallholder livestock systems in the tropics. Livest. Sci. 130, 95-109. http://dx.doi.org/10.1016/j.livsci.2010.02.014.

Mierlo, B., Arkesteijn, van, Leeuwis, M., 2010. Enhancing the reflexivity of system innovation projects with system analyses. Am. J. Eval. 31, 143-161. http://dx.doi.org/ $10.1177 / 1098214010366046$

Okali, C., Sumberg, J.E., Reddy, K.C., 1994. Unpacking a technical package: flexible messages for dynamic situations. Exp. Agric. 30, 299-310.

Paassen, A., van Ridder, N., de Stroosnijder, L., 2011. Role of an explorative model for learning about sustainable agricultural development in Burkina Faso. Int. J. Agric. Sustain. 9, 310-321. http://dx.doi.org/10.1080/14735903.2011.582360.

Ramirez, R., 1997. Understanding Farmers' Communication Networks: Combining PRA With Agricultural Knowledge Systems Analysis. Gatekeeper Series No. 66. IIED, London, UK.

Ripoche, A., Crétenet, M., Corbeels, M., Affholder, F., Naudin, K., Sissoko, F., Douzet, J. M., Tittonell, P., 2015. Cotton as an entry point for soil fertility maintenance and food crop productivity in savannah agroecosystems: evidence from a long-term experiment in southern Mali. Field Crops Res. 177, 37-48. http://dx.doi.org/10.1016/j.fcr. 2015.02.013.

Ronner, E., Franke, A.C., Vanlauwe, B., Dianda, M., Edeh, E., Ukem, B., Bala, A., van Heerwaarden, J., Giller, K.E., 2016. Understanding variability in soybean yield and response to P-fertilizer and rhizobium inoculants on farmers' fields in northern Nigeria. Field Crops Res. 186, 133-145. http://dx.doi.org/10.1016/j.fcr.2015.10. 023.

Rossing, W.A.H., Meynard, J.M., van Ittersum, M.K., 1997. Model-based explorations to support development of sustainable farming systems: case studies from France and the Netherlands. Eur. J. Agron. 7, 271-283. http://dx.doi.org/10.1016/S11610301(97)00042-7.

Rufino, M.C., Dury, J., Tittonell, P., van Wijk, M.T., Herrero, M., Zingore, S., Mapfumo, P., Giller, K.E., 2011. Competing use of organic resources, village-level interactions between farm types and climate variability in a communal area of NE Zimbabwe. Agric. Syst. 104, 175-190. http://dx.doi.org/10.1016/j.agsy.2010.06.001.

Rusike, J., Twomlow, S., Freeman, H.A., Heinrich, G.M., 2006. Does farmer participatory research matter for improved soil fertility technology development and dissemination in Southern Africa? Int. J. Agric. Sustain. 4, 176-192.

Schaap, B.F., Reidsma, P., Verhagen, J., Wolf, J., van Ittersum, M.K., 2013. Participatory design of farm level adaptation to climate risks in an arable region in The Netherlands. Eur. J. Agron. 48, 30-42. http://dx.doi.org/10.1016/j.eja.2013.02.004.

Senthilkumar, K., Bindraban, P.S., de Ridder, N., Thiyagarajan, T.M., Giller, K.E., 2012. Impact of policies designed to enhance efficiency of water and nutrients on farm households varying in resource endowments in south India. NJAS - Wageningen J. Life Sci. 59, 41-52. http://dx.doi.org/10.1016/j.njas.2012.01.002.

Snapp, S., Kanyama-Phiri, G., Kamanga, B., Gilbert, R., Wellard, K., 2002. Farmer and researcher partnerships in Malawi: developing soil fertility technologies for the nearterm and far-term. Exp. Agric. 38, 411-431. http://dx.doi.org/10.1017/ S0014479702000443.

Soumaré, M., Bazile, D., Kouressy, M., Diallo, K., Diakité, C.H., 2008. Diversité agroécosystémique et devenir des céréales traditionnelles au sud du Mali. Cah. Agric $17,79-85$.

Star, S.L., Griesemer, J.R., 1989. Institutional ecology, 'translations' and boundary objects: amateurs and professionals in Berkeley's museum of vertebrate zoology, 1907 39. Soc. Stud. Sci. 19, 387-420. http://dx.doi.org/10.1177/030631289019003001.

Sterk, B., van Ittersum, M.K., Leeuwis, C., Wijnands, F.G., 2007. Prototyping and farm system modelling - partners on the road towards more sustainable farm systems? Eur. J. Agron. 26, 401-409. http://dx.doi.org/10.1016/j.eja.2006.12.006.

Sumberg, J., Okali, C., Reece, D., 2003. Agricultural research in the face of diversity, local knowledge and the participation imperative: theoretical considerations. Agric. Syst. 76, 739-753. http://dx.doi.org/10.1016/S0308-521X(02)00153-1.

Tittonell, P., van Wijk, M.T., Herrero, M., Rufino, M.C., de Ridder, N., Giller, K.E., 2009. Beyond resource constraints - exploring the biophysical feasibility of options for the 
intensification of smallholder crop-livestock systems in Vihiga district, Kenya. Agric. Syst. 101, 1-19. http://dx.doi.org/10.1016/j.agsy.2009.02.003.

Tittonell, P., Muriuki, A., Shepherd, K.D., Mugendi, D., Kaizzi, K.C., Okeyo, J., Verchot, L., Coe, R., Vanlauwe, B., 2010. The diversity of rural livelihoods and their influence on soil fertility in agricultural systems of East Africa - a typology of smallholder farms. Agric. Syst. 103, 83-97. http://dx.doi.org/10.1016/j.agsy.2009.10.001.

Traore, S., Doumbia, A., Traore, V., Tolno, D., 2011. 4ème Recensement General De La Population Et De l'habitat Du Mali (Rgph-2009). Institut National de la, Statistique Bamako, Mali. http://www.instat-mali.org/contenu/rgph/rastr09_rgph.pdf.

Traore, B., Corbeels, M., van Wijk, M.T., Rufino, M.C., Giller, K.E., 2013. Effects of climate variability and climate change on crop production in southern Mali. Eur. J. Agron. 49, 115-125. http://dx.doi.org/10.1016/j.eja.2013.04.004.

Tumusiime, E., Brorsen, B.W., Vitale, J.D., 2014. Vertical integration in West Africa's cotton industry: are parastatals a second best solution? Agric. Econ. 45, 129-143. http://dx.doi.org/10.1111/agec.12135.

Udo, H.M.J., Aklilu, H.A., Phong, L.T., Bosma, R.H., Budisatria, I.G.S., Patil, B.R.,
Samdup, T., Bebe, B.O., 2011. Impact of intensification of different types of livestock production in smallholder crop-livestock systems. Livest. Sci. 139, 22-29. http://dx. doi.org/10.1016/j.livsci.2011.03.020.

Van Asten, P.J.A., Kaaria, S., Fermont, A.M., Delve, R.J., 2009. Challenges and lessons when using farmer knowledge in agricultural research and development projects in Africa. Exp. Agric. 45, 1-14. http://dx.doi.org/10.1017/S0014479708006984.

Whitbread, A.M., Robertson, M.J., Carberry, P.S., Dimes, J.P., 2010. How farming systems simulation can aid the development of more sustainable smallholder farming systems in southern Africa. Eur. J. Agron. 32, 51-58. http://dx.doi.org/10.1016/j.eja.2009. 05.004.

de Jager, A., Onduru, D., Gachimibi, L., Muchena, F., Gachini, G.N., 2009. Farmers Field Schools for Rural Empowerment and Life-long Learning in Integrated Nutrient Management: Experiences in Central and Eastern Kenya. In: Sanginga, P.C., WatersBayer, A., Kaaria, S., Njuki, J., Wettasinha, C. (Eds.), Innovation Africa: Enriching Farmers' Livelihoods, UK. 